\title{
The consequences of persistent inequality on social capital: A municipal-level analysis of blood donation data
}

\author{
Daniel Oto-Peralías \\ University of St Andrews \\ Diego Romero-Ávila \\ Universidad Pablo de Olavide \\ Accepted for publication at Economics Letters
}

\begin{abstract}
This letter advances the hypothesis that persistent inequality affects cultural traits and undermines social capital. We use blood donation data at the local level in Southern Spain to document that, indeed, persistent inequality -as measured by land inequality- negatively affects blood donation, which indicates that it harms social capital. This evidence sheds new light into the debates on the consequences of inequality and the determinants of culture.
\end{abstract}

Keywords: Persistent inequality, land inequality, culture, social capital, blood donation.

JEL Classification: C21, O1, O18, R1

Corresponding author: Daniel Oto-Peralías. University of St Andrews, School of Management. The Gateway, North Haugh, St Andrews, Fife, KY16 9AJ, UK. E-mail: dop2@st-andrews.ac.uk.

Diego Romero-Ávila, Pablo de Olavide University, Department of Economics, Carretera de Utrera, Km. 1, Sevilla, Spain. E-mail: dromtor@upo.es.

Acknowledgements: We are indebted to the Andalusian Health Service (Centro Regional de Transfusión Sanguínea of Seville and Dirección General de Asistencia Sanitaria y Resultados en Salud) for providing us with data on blood donors. Ivan Dondukov provided excellent research assistance. Financial support by the Carnegie Trust for the Universities of Scotland and the Spanish Ministry of Economics and Competitiveness through grant ECO2012-35430 is gratefully acknowledged.

(C) 2016. This manuscript version is made available under the CC-BY-NC-ND 4.0 license http://creativecommons.org/licenses/by-nc-nd/4.0/ 


\section{Introduction}

This article addresses an unexplored consequence of inequality: its implications for culture and social capital formation. A society suffering severe inequality may develop social and political apathy. If the situation persists for a long time, this apathy becomes a cultural trait hindering the creation of social capital. By putting forward and testing this hypothesis we contribute to the debates on the consequences of long-term inequality (e.g., Engerman and Sokoloff, 2002; Easterly, 2007; Galor et al., 2009) and the causes of culture, and more particularly, of social capital (e.g., Nunn 2012; Alesina and Giuliano 2015; Guiso et al., 2016).

We focus on the effects of historical persistent inequality -in short persistent inequality-, which refers to a type of inequality that persists over a long historical period. This persistence makes inequality a feature of society that can create cultural traits. As part of a society's culture, social capital can be undermined by persistent inequality. Arguably, an unequal society that, generations upon generations, excludes a large section of its population from having economic opportunities and acceptable living standards will hardly develop a strong sense of solidarity and commitment towards the common good. Once the cultural pattern has been created, it may persist even if society becomes more equal, thus constraining the potential for future economic growth.

We test this hypothesis using municipal-level data on blood donation in the Southern Spanish region of Andalusia (see Fig. 1). This is a case in point because Andalusia has suffered highly persistent inequality over its modern history, whose roots are largely exogenous (Oto-Peralías and Romero-Ávila, 2016a, b). In addition, blood donation is collected in a centralized way by the Andalusian Health Service, which has provided us with a unique dataset on the number of donors per municipality. We find that land inequality -as a proxy for persistent inequality- has a non-negligible negative effect on blood donation, thus supporting the hypothesis that persistent inequality undermines social capital. Interestingly, it is historical inequality rather than current inequality which affects social capital, suggesting that the effect works through the creation of cultural patterns.

\section{Background and data}

Following Guiso et al. (2011), social capital refers to "those persistent and shared beliefs and values that help a group overcome the free rider problem in the pursuit of socially valuable activities" (p. 419). We measure social capital through blood donation, which is widely considered to be a good proxy (e.g., Guiso et al., 2011; Nannicini et al., 2013). The Andalusian Health Service has provided us with a unique dataset containing the postal code 
of every person that has donated blood in any year of the period 2012-2014. Using this information and data on the population in age to donate blood (i.e., between 18 and 65), we create the variable "percentage of blood donors" at the municipal level. It is worth noting that blood donors' data comes from an ad hoc extraction from administrative files conducted specifically for this study, and postal codes may contain errors. These errors are amplified in small municipalities, for which the denominator of the indicator is smaller. In addition, inhabitants of small municipalities have less access to blood collection units. Consequently, to reduce measurement errors we exclude municipalities with less than 1,000 inhabitants in 2014, which only account for $1 \%$ of the Andalusian population. Fig. 2 depicts the Kernel density estimation of the distribution of the percentage of blood donors, which approximately follows a normal distribution slightly skewed to the right. To mitigate the influence of high values, we limit them to the $99^{\text {th }}$ percentile $(20.2 \%)$.

Our indicator of persistent inequality comes from the 1982 agricultural census and measures the percentage of utilized agricultural area in holdings with 200 hectares or more, computed considering only private agricultural holdings. This is a good proxy for historical persistent inequality because it reflects the incidence of latifundia in the municipality. Land concentration has been endemic in large parts of the Spanish and Andalusian geography, and can be traced back to the way land was colonized in the Middle Ages. Factors affecting land distribution in the remote past were contingent and exogenous to the development path of each territory (Oto-Peralías and Romero-Ávila, 2016a, b). Fig. 3 provides some evidence on the persistence of land concentration throughout the $20^{\text {th }}$ century in our sample of municipalities. Correlations are remarkably high, particularly bearing in mind that the indicators are not directly comparable. Tables A1 and A2 (Supplementary Material) provide the definitions and descriptive statistics of all variables used in the empirical analysis.

The persistent inequality suffered by municipalities characterized by high land concentration may have shaped the local culture and undermined social capital. The miserable living conditions of landless workers in Andalusia were pretty much those of a marginalized social group. Pablo de Olavide (1768/1996), Intendent of Seville in the second half of the $18^{\text {th }}$ century, described them as "the unhappiest men that I know in Europe $[\ldots]$ half-a-year laborers, and the other half beggars". This situation of inequality and dependence on the landowner persisted well into the $20^{\text {th }}$ century (Oto-Peralías and Romero-Ávila, 2016a). Arguably, a society that over a long period of time has suffered such high levels of inequality will not develop a sense of commitment towards the public good and solidarity among its members. Social groups such as landless workers that have been oppressed, marginalized, or simply placed in a systematic inferior position, are very unlikely to view 
the state (or the society as a whole) as representing or sharing their own interests. This feeling of apathy, generations upon generations, leads to a culture of lack of trust, cooperation, or more broadly, social capital.

Finally, an interesting aspect of land inequality is that it was a very important determinant of overall economic inequality in the past, while its current relevance is much lower since agriculture only employs today a small fraction of the population $(8.4 \%$ in Andalusia in 2014 according to the Labor Force Survey). Thus, in historical and cultural terms the effect of land inequality can be interpreted as a cumulative effect over time, which creates cultural patterns.

\section{Empirical results}

\subsection{Baseline results}

Column 1 of Table 1 reports the bivariate regression of the percentage of blood donors in 2014 on land concentration in 1982. The coefficient is negative and highly statistically significant, which provides initial support for our hypothesis. Column 2 adds two demographic factors that are relevant to explain blood donation, namely, total population and population's average age (in linear and quadratic terms), while column 3 includes geographic indicators such as a coast dummy, distance to the capital city (linear and squared), and a capital city dummy. In both cases the coefficient on land concentration remains negative and statistically significant. Column 4 adds additional geographic controls that may influence both blood donation and land concentration (altitude, ruggedness, soil quality, rainfall, and average temperature). This is our baseline specification. The coefficient on land inequality is large and precisely estimated. Going from a municipality without large estates ( $0 \%$ in land concentration) to a municipality with a high concentration of land $(90 \%)$ decreases blood donors by almost 2 percentage points (i.e., $(90-0) *(-0.022)=-1.98)$.

The next two columns show that the result does not depend on a specific variable of land concentration. Column 6 employs the percentage of land in holdings equal to or greater than 200 hectares from the 1962 agricultural census, while column 7 uses the percentage of land in holdings greater than 250 hectares from cadastral data in 1930. The results obtained with these alternative measures are very similar to the baseline findings. This is as expected since land distribution has remained largely unchanged over time.

\subsection{A two-stage least squared (2SLS) framework}

Following our previous work (Oto-Peralías and Romero-Ávila, 2016a, b), we argue that land inequality can be largely considered as an exogenous factor due to the way the territory was colonized in the Middle Ages after the Christian conquest. This fact makes us confident 
that the uncovered negative effect of persistent inequality on social capital is not driven by reverse causality or omitted variables. To further pursue this issue, this section explicitly exploits the fact that Andalusia was divided during the Middle Ages by a frontier that ceased to exist in 1492 when the Catholic Monarchs conquered the Nasrid Kingdom of Granada (see Fig. 1). The Castilian part of Andalusia was colonized under the conditions of an insecure frontier region, which led to the concentration of land in the hands of the military elite, i.e., the nobility. In contrast, once conquered, the former Nasrid Kingdom of Granada was colonized under very different premises, that is, as a secure region, with land distribution evolving in a relatively more equal way (see details in Oto-Peralías and Romero-Ávila, 2016b). Since the territory close to the frontier is geographically very similar (as shown in Table 2 in Oto-Peralías and Romero-Ávila, 2016b), we can use this historical accident as a source of exogenous variation in persistent inequality within a 2SLS framework.

Columns 1 and 2 of Table 2 employ the whole sample, while columns 3 and 4 focus on municipalities within $25 \mathrm{~km}$ of the frontier. The instrument is a dummy variable capturing whether the municipality belonged to the Castilian part of Andalusia in the Middle Ages. This variable exerts a strong positive effect on land concentration, thereby indicating that it is a relevant instrument. The second stage, which uses only that part of land concentration that is due to the frontier dummy, reports a large, negative, and highly significant coefficient. The increase in the size of the effect suggests that the OLS estimates are downward biased. Moreover, it could suggest that the exclusion restriction does not hold. In this regard, one possible interpretation is that, as documented in Oto-Peralías and Romero-Ávila (2016b), the frontier of Granada also affected the concentration of political power by the nobility. Thus, if we consider the second-stage coefficient on land concentration to be capturing inequality in a broad sense (both in economic and political terms), this would also justify its larger effect. Notwithstanding, due to lack of data on other potential channels, it is impossible to test whether the frontier has only affected social capital through persistent inequality. Therefore, we cannot assure that persistent inequality is the only channel through which the presence of the frontier of Granada affected social capital, but it is likely to be the dominant one. All in all, this 2SLS exercise provides evidence consistent with the hypothesis that persistent inequality undermines social capital.

\subsection{Additional robustness checks}

Our reading of the results is that persistent inequality -proxied by land concentrationcontributes to create a culture of low cooperation and low commitment towards the common good, which means low social capital. Therefore, this implies that persistent inequality has 
direct cultural implications. An alternative interpretation would be that persistent inequality harms economic development in the long-run, with poorer communities ending up with less social capital. This would imply an indirect effect working through economic development. We try to address this issue by adding proxies for income to our baseline model. Columns 1 to 4 of Table 3 control for the percentage of population with secondary and higher education, the average number of vehicles per household, average socio-economic condition, and average gross income. All these variables enter with a positive coefficient, which is statistically significant only in column 3 . Reassuringly, the coefficient on land concentration remains unchanged.

One may also wonder whether it is current inequality, rather than historical inequality, what matters. Current inequality can be measured through income inequality in 2007. Data on this variable at the local level is seldom available. For the Spanish case, there are data available for municipalities larger than 5,000 inhabitants (Hortas-Rico and Onrubia, 2014). Column 5 estimates our baseline model with this smaller sample of municipalities. The coefficient on land concentration is larger, which is likely due to the fact that measurement errors in the dependent variable diminish as municipality size increases. Column 6 includes an income Gini index, which enters with a negative but statistically insignificant coefficient. Column 7 includes both inequality variables. Remarkably, the coefficient on persistent inequality (i.e., land concentration) remains negative and significant, while that on current inequality is again insignificant.

Finally, our findings are also robust to: i) correcting standard errors for spatial dependence; ii) trimming values of the percentage of blood donors at the $95^{\text {th }}$ percentile (rather than at the $99^{\text {th }}$ ); iii) applying different cutoffs of municipalities' population; and iv) using electoral turnout as an alternative indicator of social capital (see Supplementary Material for details).

\section{Conclusions}

This letter advances and tests the hypothesis that persistent inequality undermines social capital. Using data on blood donors as a proxy for social capital, and land concentration as a measure of persistent inequality, our municipal-level analysis finds support for this hypothesis. Land inequality exerts a non-negligible negative effect on the percentage of blood donors, which is robust to the inclusion of a wide array of demographic and geographic controls. The effect is also robust to controlling for several proxies for income, which suggests that our findings are not driven by the fact that inequality negatively affects economic growth. In addition, we find that what matters is historical inequality rather than current (income) inequality. This is consistent with the fact that once the cultural trait is 
created, it may persist even if society becomes more equal. In all, the evidence provided sheds new light into the debates on the consequences of inequality and the determinants of culture.

\section{References}

Alesina, A., and Giuliano, P. 2015. "Culture and Institutions." Journal of Economic Literature, 53: 898-944.

Easterly, W. 2007. "Inequality Does Cause Underdevelopment: Insights from a new instrument." Journal of Development Economics 84: 755-776.

Engerman, S. L., and Sokoloff, K. L. 2002. "Factor endowments, inequality, and paths of development among new world economies." Economia, 3: 41-109.

Galor, O., Moav, O., and Vollrath, D. 2009. "Inequality in land ownership, the emergence of human capital promoting institutions and the great divergence." Review of Economic Studies, 76: $143-179$.

Guiso, L., Sapienza, P, and Zingales, L. 2011. "Civic Capital as the Missing Link." In Social Economics Handbook, edited by Benhabib, J., Bisin, A. and Jackson. M. North-Holland.

Guiso, L., Sapienza, P. and Zingales, L. 2016. "Long-term persistence." Journal of the European Economic Association. doi:10.1111/jeea.12177

Hortas-Rico, M. and Onrubia, J. 2014. "Renta personal de los municipios españoles y su distribución: metodología de estimación a partir de microdatos tributarios", Estudios sobre la Economía Española 2014-12, FEDEA.

Nannicini, T., Stella, A., Tabellini, G., and Troiano, U. 2013. "Social Capital and Political Accountability." American Economic Journal: Economic Policy, 5(2): 222-50.

Nunn, N. 2012. "Culture and the Historical Process". Economic History of Developing Regions, 27(S1):108-126.

Olavide, Pablo de. 1768/1996. Informe sobre la Ley Agraria. In La Reforma Agraria en Andalucía: el Primer Proyecto Legislativo, edited by Merchán, A. Sevilla: Universidad de Sevilla.

Oto-Peralías, D. and Romero-Ávila D. 2016a. "The Economic Consequences of the Spanish Reconquest: The Long-term Effects of Medieval Conquest and Colonization", Journal of Economic Growth, doi:10.1007/s10887-016-9132-9.

Oto-Peralías, D. and Romero-Ávila D. 2016b. "Historical Frontiers and the Rise of Inequality. The Case of the Frontier of Granada", Journal of the European Economic Association, forthcoming. 


\section{TABLES AND FIGURES}

\section{Table 1}

The effect of land concentration on blood donation: Baseline results

\section{Dependent variable is the percentage of blood donors}

\begin{tabular}{|c|c|c|c|c|c|c|}
\hline & (1) & $(2)$ & $(3)$ & (4) & (5) & (6) \\
\hline Land concentration in 1982 & $\begin{array}{c}-0.017 * * * \\
(0.006)\end{array}$ & $\begin{array}{c}-0.014 * * \\
(0.006)\end{array}$ & $\begin{array}{c}-0.022 * * * \\
(0.006)\end{array}$ & $\begin{array}{c}-0.022 * * * \\
(0.007)\end{array}$ & & \\
\hline Land concentration in 1962 & & & & & $\begin{array}{c}-0.015 * * * \\
(0.005)\end{array}$ & \\
\hline Land concentration in 1930 & & & & & & $\begin{array}{c}-0.02 * * * \\
(0.005)\end{array}$ \\
\hline Population & & $\begin{array}{c}-0.04 * * * \\
(0.006)\end{array}$ & $\begin{array}{c}-0.027 * * * \\
(0.006)\end{array}$ & $\begin{array}{c}-0.025 * * * \\
(0.006)\end{array}$ & $\begin{array}{c}-0.026 * * * \\
(0.006)\end{array}$ & $\begin{array}{c}-0.032 * * * \\
(0.007)\end{array}$ \\
\hline Population squared & & $\begin{array}{c}56.945 * * * \\
(10.756)\end{array}$ & $\begin{array}{c}33.427 * * * \\
(8.885)\end{array}$ & $\begin{array}{c}31.325 * * * \\
(9.022)\end{array}$ & $\begin{array}{c}32.554 * * * \\
(8.998)\end{array}$ & $\begin{array}{c}57.143 * * * \\
(10.144)\end{array}$ \\
\hline Population's average age & & $\begin{array}{c}3.256 * * * \\
(0.622)\end{array}$ & $\begin{array}{c}2.544 * * * \\
(0.615)\end{array}$ & $\begin{array}{c}2.112 * * * \\
(0.613)\end{array}$ & $\begin{array}{c}2.005 * * * \\
(0.628)\end{array}$ & $\begin{array}{l}1.601 * * \\
(0.707)\end{array}$ \\
\hline Population's average age squared & & $\begin{array}{c}-0.036 * * * \\
(0.008)\end{array}$ & $\begin{array}{c}-0.029 * * * \\
(0.007)\end{array}$ & $\begin{array}{c}-0.024 * * * \\
(0.007)\end{array}$ & $\begin{array}{c}-0.023 * * * \\
(0.008)\end{array}$ & $\begin{array}{c}-0.018 * * \\
(0.009)\end{array}$ \\
\hline Coast dummy & & & $\begin{array}{c}-2.708 * * * \\
(0.278)\end{array}$ & $\begin{array}{c}-2.27 * * * \\
(0.366)\end{array}$ & $\begin{array}{c}-2.24 * * * \\
(0.381)\end{array}$ & $\begin{array}{c}-2.417 * * * \\
(0.414)\end{array}$ \\
\hline Distance to capital city & & & $\begin{array}{c}4.516 * * \\
(1.792)\end{array}$ & $\begin{array}{c}5.487 * * * \\
(1.988)\end{array}$ & $\begin{array}{l}4.965 * * \\
(2.002)\end{array}$ & $\begin{array}{c}5.793 * * \\
(2.28)\end{array}$ \\
\hline Distance to capital city squared & & & $\begin{array}{l}-2.464 \\
(1.583)\end{array}$ & $\begin{array}{c}-3.554 * * \\
(1.773)\end{array}$ & $\begin{array}{l}-3.22 * \\
(1.775)\end{array}$ & $\begin{array}{c}-4.123 * * \\
(1.969)\end{array}$ \\
\hline Capital city dummy & & & $\begin{array}{c}2.834 * * \\
(1.356)\end{array}$ & $\begin{array}{l}3.132 * * \\
(1.413)\end{array}$ & $\begin{array}{c}3.005 * * \\
(1.463)\end{array}$ & $\begin{array}{l}2.197 * \\
(1.272)\end{array}$ \\
\hline Altitude & & & & $\begin{array}{l}0.002 * \\
(0.001)\end{array}$ & $\begin{array}{l}0.002 * \\
(0.001)\end{array}$ & $\begin{array}{c}0.002 \\
(0.001)\end{array}$ \\
\hline Ruggedness & & & & $\begin{array}{l}-0.003 * \\
(0.002)\end{array}$ & $\begin{array}{l}-0.002 \\
(0.002)\end{array}$ & $\begin{array}{l}-0.001 \\
(0.002)\end{array}$ \\
\hline Soil quality & & & & $\begin{array}{l}0.028 \\
(0.25)\end{array}$ & $\begin{array}{l}-0.091 \\
(0.266)\end{array}$ & $\begin{array}{c}0.028 \\
(0.283)\end{array}$ \\
\hline Rainfall & & & & $\begin{array}{l}0.149 * \\
(0.085)\end{array}$ & $\begin{array}{c}0.13 \\
(0.083)\end{array}$ & $\begin{array}{c}0.061 \\
(0.115)\end{array}$ \\
\hline Average temperature & & & & $\begin{array}{c}0.09 \\
(0.187)\end{array}$ & $\begin{array}{c}0.077 \\
(0.188)\end{array}$ & $\begin{array}{c}0.14 \\
(0.211)\end{array}$ \\
\hline$R$-squared & 0.01 & 0.17 & 0.23 & 0.24 & 0.23 & 0.24 \\
\hline Obs. & 570 & 570 & 570 & 570 & 569 & 509 \\
\hline
\end{tabular}

Notes: Variables descriptions are provided in Table A1 (Supplementary Material). All regressions are estimated by OLS. The estimations include a constant term, which is omitted for space considerations. Robust standard errors are in parentheses. ${ }^{*}, * *$ and $* * *$ denote statistical significance at the 10,5 and $1 \%$ level, respectively. 
Table 2

The effect of land concentration on blood donation: A 2SLS exercise

Dependent variable in the second stage is the percentage of blood donors

$\frac{\text { Whole sample }}{\text { First stage Second stage }} \quad \frac{\begin{array}{c}\text { Within } 25 \mathrm{~km} \text { of the } \\ \text { Frontier }\end{array}}{\text { First stage Second stage }}$

\begin{tabular}{lcccc} 
& $(1)$ & $(2)$ & $(3)$ & $(4)$ \\
\hline Land concentration in 1982 & & $-0.109^{* * *}$ & & $-0.164^{* *}$ \\
& & $(0.038)$ & & $(0.081)$ \\
Castilian part of Andalusia & $11.744^{* * *}$ & & $8.802^{* * *}$ & \\
& $(1.951)$ & & $(2.839)$ & \\
Demographic and geographic controls & Yes & Yes & Yes & Yes \\
$F$-stat of the instrument & 36.220 & & 9.613 & \\
Partial $R$-squared & 0.050 & & 0.060 & \\
$R$-squared & 0.219 & & 0.292 & \\
Obs. & 570 & 570 & 167 & 167 \\
\hline
\end{tabular}

Notes: Variables descriptions are provided in Table A1 (Supplementary Material). All regressions are estimated by 2 SLS. The estimations include a constant term, which is omitted for space considerations. Robust standard errors are in parentheses. *,** and *** denote statistical significance at the 10,5 and $1 \%$ level, respectively.

Table 3

Robustness to alternative interpretations

Dependent variable is the percentage of blood donors

\begin{tabular}{|c|c|c|c|c|c|c|c|}
\hline & (1) & (2) & (3) & (4) & (5) & (6) & (7) \\
\hline Land concentration in 1982 & $\begin{array}{c}-0.022 * * * \\
(0.007)\end{array}$ & $\begin{array}{c}-0.022 * * * \\
(0.007)\end{array}$ & $\begin{array}{l}-0.020 * * * \\
(0.007)\end{array}$ & $\begin{array}{c}-0.022 * * * \\
(0.007)\end{array}$ & $\begin{array}{c}-0.028 * * * \\
(0.007)\end{array}$ & & $\begin{array}{c}-0.029 * * * \\
(0.007)\end{array}$ \\
\hline Education level (2001) & $\begin{array}{c}0.009 \\
(0.016)\end{array}$ & & & & & & \\
\hline $\begin{array}{l}\text { Average number of vehicles per } \\
\text { household (2001) }\end{array}$ & & $\begin{array}{c}0.15 \\
(1.155)\end{array}$ & & & & & \\
\hline $\begin{array}{l}\text { Average socio-economic condition } \\
\text { (2001) }\end{array}$ & & & $\begin{array}{l}3.028^{*} \\
(1.751)\end{array}$ & & & & \\
\hline Average gross income (2013) & & & & $\begin{array}{c}0.79 \\
(0.703)\end{array}$ & & & \\
\hline Income Gini index (2007) & & & & & & $\begin{array}{l}-1.367 \\
(2.771)\end{array}$ & $\begin{array}{c}-3.034 \\
(2.578)\end{array}$ \\
\hline Demographic and geographic controls & Yes & Yes & Yes & Yes & Yes & Yes & Yes \\
\hline$R$-squared & 0.240 & 0.24 & 0.240 & 0.240 & 0.400 & 0.370 & 0.41 \\
\hline Obs. & 569 & 569 & 569 & 570 & 234 & 236 & 234 \\
\hline
\end{tabular}

Notes: Variables descriptions are provided in Table A1 (Supplementary Material). All regressions are estimated by OLS. The estimations include a constant term, which is omitted for space considerations. Robust standard errors are in parentheses. *, ** and *** denote statistical significance at the 10,5 and $1 \%$ level, respectively. 


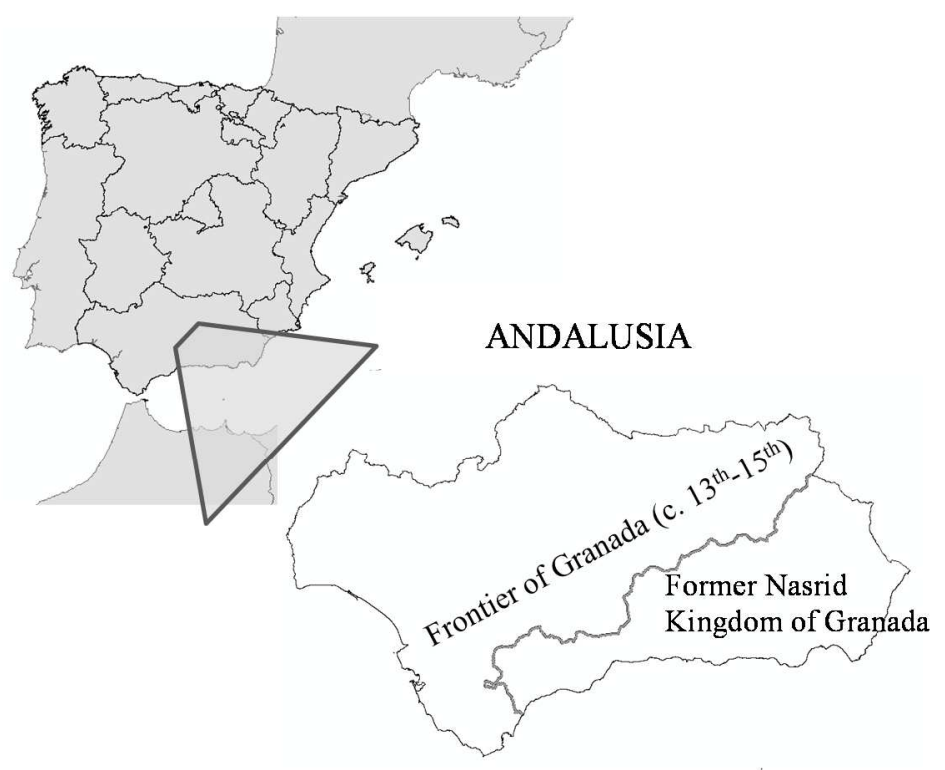

Fig. 1. Geographical context

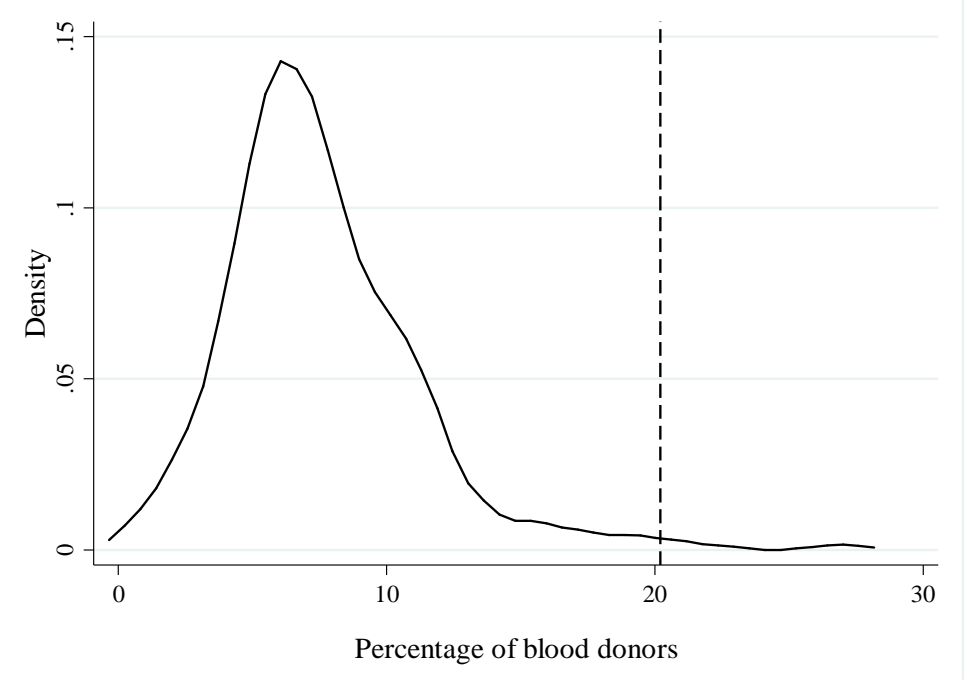

Fig. 2. Kernel density of the percentage of blood donors

Note: The vertical line reflects the value at which values are trimmed in the analysis (the 99th percentile). 


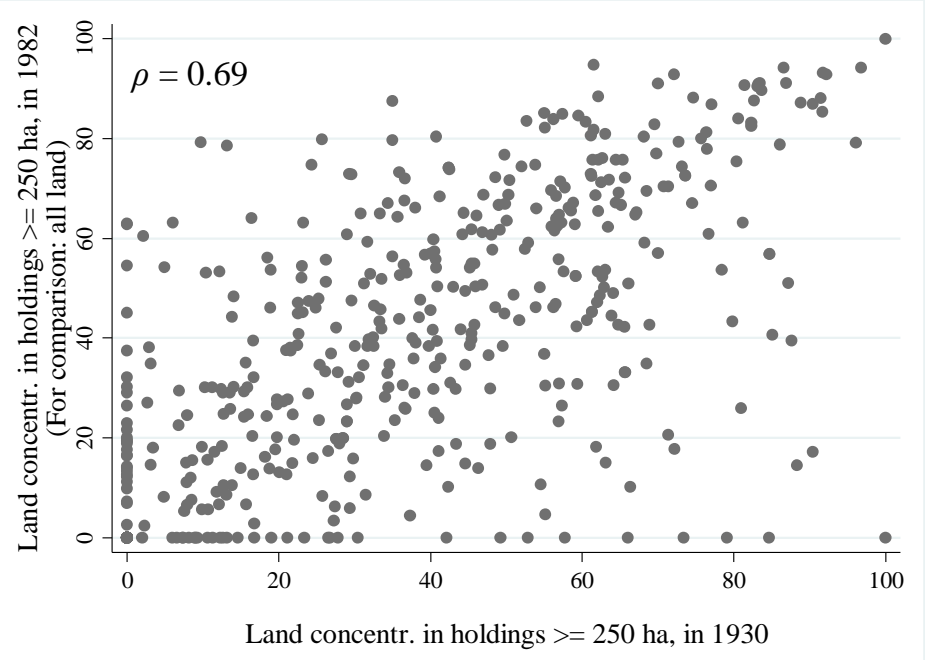

Panel A. Land concentration in 1982 (for comparison*) and 1930 (cadastral data)

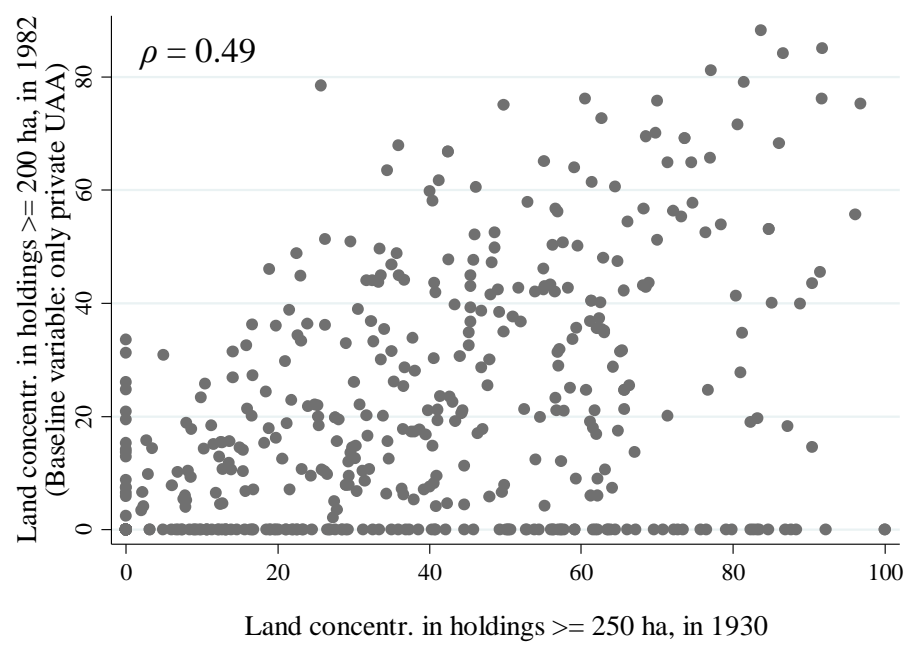

Panel B. Land concentration in 1982 (baseline indicator) and 1930 (cadastral data)

Fig. 3. Persistence in land concentration

Note: *Land concentration in 1982 in Panel A has been created for comparison purposes with the measure of 1930, which considers all types of land (see more details in Table A1). 


\title{
Supplementary Material to
}

\section{The consequences of persistent inequality on social capital: A municipal-level analysis of blood donation data}

\author{
Daniel Oto-Peralías \\ University of St Andrews \\ Diego Romero-Ávila \\ Universidad Pablo de Olavide
}

This appendix includes:

Table A1. Description of variables.

Table A2. Descriptive statistics.

Table A3. Replication of Table 1 with standard errors corrected for spatial dependence.

Table A4. Replication of Table 1 with values of the percentage of blood donors trimmed at the $95^{\text {th }}$ percentile (rather than at the $99^{\text {th }}$ ).

Table A5. Baseline model for different cutoffs of municipalities' population.

Table A6. An alternative indicator of social capital: Turnout in general elections. 
Table A1

Description of variables

\begin{tabular}{ll}
\hline \multicolumn{1}{c}{ Variable } & \multicolumn{1}{c}{ Description } \\
\hline Altitude & $\begin{array}{l}\text { Average altitude in meters, computed using GIS } \\
\text { software. }\end{array}$ \\
& \\
Average gross income & $\begin{array}{l}\text { Logarithm of 'gross personal income divided by the } \\
\text { population aged between 18 and 65 years'. The } \\
\text { informacion is collected from tax returns of the income } \\
\text { tax of individuals (IRPF). The year of measurement is }\end{array}$ \\
& $\begin{array}{l}\text { 2013. } \\
\text { Number of vehicles (cars and vans) for personal } \\
\text { transport owned by households, divided by the number } \\
\text { of households. The year of measurement is 2001. }\end{array}$ \\
Average & $\begin{array}{l}\text { Average of class marks of socioeconomic conditions of } \\
\text { individuals, combining information from occupation, } \\
\text { activity and professional situation. To illustrate the } \\
\text { condition } \\
\text { construction of this variable, a (maximum) class mark } \\
\text { of } 3 \text { is given to non-agricultural entrepreneurs with } \\
\text { employees, and a (minimun) class mark of 0 to those } \\
\text { unemployed who have not worked previously. Year } \\
\text { 2001. }\end{array}$
\end{tabular}

Average temperature Annual average temperature (in degrees Celsius).

Authors' elaboration using geo-referenced data from Instituto de Estadística y Cartografía de Andalucía (IECA) (2014a).

Capital city dummy Dummy variable capturing whether the municipality is Authors' elaboration. the capital city of the province

Castilian part of Dummy variable indicating whether the municipality Andalusia belonged to the Castilian part of Andalusia.

Oto-Peralías and RomeroÁvila (2016b).

Coast dummy Dummy variable indicating whether the municipality

Authors' elaboration. has access to the coast.

Distance to capital city Linear distance between the centroid of the

Authors' elaboration. municipality and its capital city (in hundreds $\mathrm{km}$ ), computed using GIS software.

Education level Percentage of population with secondary or higher education. Year 2001.

INE. Censos de Población y Viviendas 2001.

Income Gini index

Gini index corresponding to the distribution of the gross Hortas-Rico y Onrubia personal income in 2007.

(2014). 
Table A1

Description of variables (Continued)

\begin{tabular}{|c|c|c|}
\hline Variable & Description & Source \\
\hline $\begin{array}{l}\text { Land concentration in } \\
1930\end{array}$ & $\begin{array}{l}\text { Percentage of land in holdings greater than } 250 \text { hectares } \\
\text { in 1930, from cadastral data. Due to data availability, } \\
\text { this indicator considers all types of land. }\end{array}$ & Carrión (1975). \\
\hline $\begin{array}{l}\text { Land concentration in } \\
1962\end{array}$ & $\begin{array}{l}\text { Percentage of land in holdings greater than } 200 \\
\text { hectares, measured in } 1962 . \text { Due to data availability, } \\
\text { this indicator considers all types of land (i.e., the whole } \\
\text { census area). }\end{array}$ & $\begin{array}{l}1962 \text { agricultural census } \\
\text { (INE). }\end{array}$ \\
\hline $\begin{array}{l}\text { Land concentration in } \\
1982\end{array}$ & $\begin{array}{l}\text { Percentage of UAA in holdings equal to or greater than } \\
200 \text { hectares of UAA, in } 1982 \text {. We focus on private } \\
\text { agricultural holdings (with legal status of natural person } \\
\text { or company), which represent } 95 \% \text { of total UAA. }\end{array}$ & $\begin{array}{l}\text { Authors' elaboration using } \\
\text { the } 1982 \text { agricultural census } \\
\text { (INE). }\end{array}$ \\
\hline
\end{tabular}

Land concentration in For comparison purposes with "land concentration in Authors' elaboration using 1982 (Panel A of Figure 3) $1930 "$, this variable measures the percentage of land in holdings equal to or greater than 250 hectares in 1982. (INE). All types of land are considered.

Percentage of blood Number of blood donors divided by the population donors

Population

Population's average age

Rainfall

Ruggedness

Soil quality

Turnout in general elections

aged between 18 and 65 years, which is the age at in any year of 2012, 2013, and 2014. squared term is expressed in millions. Year 2014. Average age of the population. Year 2014. using GIS software. software. 1989-2011. which an individual is eligible to donate blood. A person Health Service (Centro is considered a blood donor if he/she has donated blood Regional de Transfusión

Sanguínea of Seville) and INE (Padrón Municipal).

INE. Padrón Municipal.

INE. Padrón Municipal.

Authors' elaboration using geo-referenced data from IECA (2014a).

Authors' elaboration using geo-referenced data from Hijmans et al. (2005).

Indicator of soil quality calculated as: $4 *(\%$ surface area Consejería de Medio with excellent soil capacity $)+3 *(\%$ surface area with Ambiente. Junta de good soil capacity $)+2 *(\%$ surface area with moderate Andalucía (1996). soil capacity $)+1 *(\%$ surface area with marginal soil capacity), with values ranging from 1 (low soil quality) to 4 (excellent soil quality). It is computed using GIS

Average turnout in general elections during the period Authors' elaboration using data from IECA (2014b). 
Table A1

Description of variables (Continued)

Notes and references:

Notes:

The basic layer with the administrative limits of the Andalusian municipalities, used in the variables computed with GIS software, comes from IECA (2014a).

References:

Carrión, P. 1975. Los Latifundios en España. Su importancia, Origen, Consecuencias y Solución. Barcelona: Ariel.

Consejería de Medio Ambiente, 1996. Mapa de Capacidad de Uso General y Erosión de las tierras de Andalucía a escala 1:400.000. Consejería de Medio Ambiente. Junta de Andalucía. Año 1996.

Hijmans, R.J., S.E. Cameron, J.L. Parra, P.G. Jones and A. Jarvis, 2005. "Very high resolution interpolated climate surfaces for global land areas." International Journal of Climatology 25: 1965-1978.

Hortas-Rico, M. and Onrubia, J. 2014. "Renta personal de los municipios españoles y su distribución: metodología de estimación a partir de microdatos tributarios", Estudios sobre la Economía Española 201412, FEDEA.

Instituto de Estadística y Cartografía de Andalucía, 2014a. Datos Espaciales de Referencia de Andalucía. Available at http://www.juntadeandalucia.es/institutodeestadisticaycartografia/

Instituto de Estadística y Cartografía de Andalucía, 2014b. Sistema de Información Multiterritorial de Andalucía. Available at http://www.juntadeandalucia.es/institutodeestadisticaycartografia/

Instituto Nacional de Estadística (INE). Variables are available at www.ine.es

Oto-Peralías, D. and Romero-Ávila D. 2016b. "Historical Frontiers and the Rise of Inequality. The Case of the Frontier of Granada", Journal of the European Economic Association, forthcoming. 
Table A2

Descriptive statistics

\begin{tabular}{|c|c|c|c|c|c|}
\hline Variable & Obs & Mean & Std. Dev. & Min & Max \\
\hline Altitude & 572 & 493.56 & 371.92 & 2.02 & 1878.49 \\
\hline Average gross income & 572 & 2.23 & 0.22 & 1.62 & 3.01 \\
\hline $\begin{array}{l}\text { Average number of vehicles per } \\
\text { household }\end{array}$ & 571 & 0.85 & 0.16 & 0.42 & 1.44 \\
\hline Average socioeconomic condition & 571 & 0.78 & 0.09 & 0.55 & 1.06 \\
\hline Average temperature & 572 & 15.40 & 1.75 & 8.59 & 19.00 \\
\hline Capital city dummy & 572 & 0.01 & 0.12 & 0.00 & 1.00 \\
\hline Castilian part of Andalusia & 572 & 0.62 & 0.49 & 0.00 & 1.00 \\
\hline Coast dummy & 572 & 0.10 & 0.30 & 0.00 & 1.00 \\
\hline Distance to capital city & 572 & 0.44 & 0.26 & 0.00 & 1.34 \\
\hline Education level & 571 & 46.45 & 10.55 & 13.00 & 82.00 \\
\hline Income Gini index & 236 & 0.45 & 0.04 & 0.20 & 0.61 \\
\hline Land concentration in 1930 & 509 & 34.79 & 26.93 & 0.00 & 100.00 \\
\hline Land concentration in 1962 & 569 & 40.11 & 26.61 & 0.00 & 99.58 \\
\hline Land concentration in 1982 & 570 & 17.36 & 20.93 & 0.00 & 88.28 \\
\hline $\begin{array}{l}\text { Land concentration in } 1982 \\
\text { (Panel A of Figure 3) }\end{array}$ & 570 & 37.25 & 28.36 & 0.00 & 99.89 \\
\hline Percentage of blood donors & 572 & 7.55 & 3.46 & 0.42 & 20.18 \\
\hline Population & 572 & 14.51 & 45.73 & 1.00 & 696.68 \\
\hline Population's average age & 572 & 41.49 & 3.52 & 32.84 & 52.99 \\
\hline Rainfall & 572 & 6.70 & 1.95 & 2.00 & 18.47 \\
\hline Ruggedness & 572 & 125.02 & 114.26 & 0.61 & 893.33 \\
\hline Soil quality & 572 & 1.99 & 0.67 & 1.00 & 4.00 \\
\hline Turnout in general elections & 570 & 77.94 & 5.48 & 57.52 & 90.07 \\
\hline
\end{tabular}

Notes: Variables descriptions are provided in Table A1. 
Table A3

Replication of Table 1 with standard errors corrected for spatial dependence

\begin{tabular}{|c|c|c|c|c|c|c|}
\hline \multicolumn{7}{|c|}{ Dependent variable is Percentage of blood donors } \\
\hline & $(1)$ & (2) & (3) & (4) & (5) & (6) \\
\hline Land concentration in 1982 & $\begin{array}{c}-0.017 * \\
{[0.009]}\end{array}$ & $\begin{array}{l}-0.014 * \\
{[0.008]}\end{array}$ & $\begin{array}{c}-0.022 * * \\
{[0.009]}\end{array}$ & $\begin{array}{c}-0.022 * * \\
{[0.01]}\end{array}$ & & \\
\hline Land concentration in 1962 & & & & & $\begin{array}{c}-0.015 * * * \\
{[0.006]}\end{array}$ & \\
\hline Land concentration in 1930 & & & & & & $\begin{array}{c}-0.02 * * * \\
{[0.006]}\end{array}$ \\
\hline Population & & $\begin{array}{c}-0.04 * * * \\
{[0.007]}\end{array}$ & $\begin{array}{c}-0.027 * * * \\
{[0.008]}\end{array}$ & $\begin{array}{c}-0.025 * * * \\
{[0.008]}\end{array}$ & $\begin{array}{c}-0.026^{* * * *} \\
{[0.009]}\end{array}$ & $\begin{array}{c}-0.032 * * * \\
{[0.01]}\end{array}$ \\
\hline Population squared & & $\begin{array}{c}56.945^{* * *} \\
{[12.334]}\end{array}$ & $\begin{array}{c}33.427 * * * \\
{[11.469]}\end{array}$ & $\begin{array}{c}31.325^{* * *} \\
{[11.975]}\end{array}$ & $\begin{array}{c}32.554 * * \\
{[12.709]}\end{array}$ & $\begin{array}{c}57.143 * * * \\
{[15.334]}\end{array}$ \\
\hline Population's average age & & $\begin{array}{c}3.256^{* * *} \\
{[1.133]}\end{array}$ & $\begin{array}{l}2.544 * * \\
{[0.996]}\end{array}$ & $\begin{array}{c}2.112 * * \\
{[0.863]}\end{array}$ & $\begin{array}{c}2.005^{* *} \\
{[0.846]}\end{array}$ & $\begin{array}{c}1.601 \\
{[1.061]}\end{array}$ \\
\hline Population's average age squared & & $\begin{array}{c}-0.036 * * * \\
{[0.014]}\end{array}$ & $\begin{array}{c}-0.029 * * \\
{[0.012]}\end{array}$ & $\begin{array}{c}-0.024^{* *} \\
{[0.011]}\end{array}$ & $\begin{array}{c}-0.023 * * \\
{[0.01]}\end{array}$ & $\begin{array}{c}-0.018 \\
{[0.013]}\end{array}$ \\
\hline Coast dummy & & & $\begin{array}{c}-2.708 * * * \\
{[0.417]}\end{array}$ & $\begin{array}{c}-2.27 * * * \\
{[0.537]}\end{array}$ & $\begin{array}{c}-2.24 * * * \\
{[0.563]}\end{array}$ & $\begin{array}{c}-2.417 * * * \\
{[0.566]}\end{array}$ \\
\hline Distance to capital city & & & $\begin{array}{c}4.516 \\
{[3.041]}\end{array}$ & $\begin{array}{l}5.487^{*} \\
{[2.86]}\end{array}$ & $\begin{array}{l}4.965^{*} \\
{[2.823]}\end{array}$ & $\begin{array}{l}5.793 * \\
{[3.175]}\end{array}$ \\
\hline Distance to capital city squared & & & $\begin{array}{l}-2.464 \\
{[2.607]}\end{array}$ & $\begin{array}{l}-3.554 \\
{[2.467]}\end{array}$ & $\begin{array}{c}-3.22 \\
{[2.453]}\end{array}$ & $\begin{array}{l}-4.123 \\
{[2.65]}\end{array}$ \\
\hline Capital city dummy & & & $\begin{array}{l}2.834^{*} \\
{[1.466]}\end{array}$ & $\begin{array}{c}3.132 * * \\
{[1.497]}\end{array}$ & $\begin{array}{l}3.005^{* *} \\
{[1.461]}\end{array}$ & $\begin{array}{l}2.197 \\
{[1.55]}\end{array}$ \\
\hline Altitude & & & & $\begin{array}{l}0.002^{*} \\
{[0.001]}\end{array}$ & $\begin{array}{l}0.002^{*} \\
{[0.001]}\end{array}$ & $\begin{array}{c}0.002 \\
{[0.001]}\end{array}$ \\
\hline Ruggedness & & & & $\begin{array}{c}-0.003 \\
{[0.002]}\end{array}$ & $\begin{array}{c}-0.002 \\
{[0.003]}\end{array}$ & $\begin{array}{c}-0.001 \\
{[0.002]}\end{array}$ \\
\hline Soil quality & & & & $\begin{array}{c}0.028 \\
{[0.266]}\end{array}$ & $\begin{array}{c}-0.091 \\
{[0.266]}\end{array}$ & $\begin{array}{c}0.028 \\
{[0.267]}\end{array}$ \\
\hline Rainfall & & & & $\begin{array}{c}0.149 \\
{[0.099]}\end{array}$ & $\begin{array}{c}0.13 \\
{[0.091]}\end{array}$ & $\begin{array}{c}0.061 \\
{[0.121]}\end{array}$ \\
\hline Average temperature & & & & $\begin{array}{c}0.09 \\
{[0.229]}\end{array}$ & $\begin{array}{c}0.077 \\
{[0.235]}\end{array}$ & $\begin{array}{c}0.14 \\
{[0.25]}\end{array}$ \\
\hline$R$-squared & 0.01 & 0.17 & 0.23 & 0.24 & 0.23 & 0.24 \\
\hline Obs. & 570 & 570 & 570 & 570 & 569 & 509 \\
\hline
\end{tabular}

Notes: Variables descriptions are provided in Table A1 (Supplementary Material). All regressions are estimated by OLS. The estimations include a constant term, which is omitted for space considerations. Conley's standard errors (i.e., corrected for spatial dependence) are in brackets. We employ cutoffs of 1 decimal degree, beyond which spatial correlation is assumed to be zero. *, ** and *** denote statistical significance at the 10,5 and $1 \%$ level, respectively. 


\section{Table A4}

Replication of Table 1 with values of the percentage of blood donors trimmed at the $95^{\text {th }}$ percentile (rather than at the $99^{\text {th }}$ )

\begin{tabular}{|c|c|c|c|c|c|c|}
\hline \multicolumn{7}{|c|}{ Dependent variable is Percentage of blood donors } \\
\hline & $(1)$ & (2) & (3) & (4) & (5) & (6) \\
\hline Land concentration in 1982 & $\begin{array}{c}-0.015 * * \\
(0.006)\end{array}$ & $\begin{array}{c}-0.012 * * \\
(0.005)\end{array}$ & $\begin{array}{c}-0.018 * * * \\
(0.005)\end{array}$ & $\begin{array}{c}-0.017 * * * \\
(0.006)\end{array}$ & & \\
\hline Land concentration in 1962 & & & & & $\begin{array}{c}-0.013 * * * \\
(0.005)\end{array}$ & \\
\hline Land concentration in 1930 & & & & & & $\begin{array}{c}-0.018 * * * \\
(0.005)\end{array}$ \\
\hline Population & & $\begin{array}{c}-0.038^{* * * *} \\
(0.006)\end{array}$ & $\begin{array}{c}-0.025^{* * * *} \\
(0.005)\end{array}$ & $\begin{array}{c}-0.023^{* * * *} \\
(0.006)\end{array}$ & $\begin{array}{c}-0.024^{* * * *} \\
(0.005)\end{array}$ & $\begin{array}{c}-0.029 * * * \\
(0.006)\end{array}$ \\
\hline Population squared & & $\begin{array}{c}54.121 * * * \\
(10.237)\end{array}$ & $\begin{array}{c}31.622 * * * * \\
(8.424)\end{array}$ & $\begin{array}{c}29.419 * * * \\
(8.477)\end{array}$ & $\begin{array}{c}30.308^{* * * *} \\
(8.397)\end{array}$ & $\begin{array}{c}52.957 * * * \\
\quad(9.13)\end{array}$ \\
\hline Population's average age & & $\begin{array}{c}2.917 * * * \\
(0.571)\end{array}$ & $\begin{array}{c}2.346 * * * \\
(0.576)\end{array}$ & $\begin{array}{c}2.005^{* * * *} \\
(0.579)\end{array}$ & $\begin{array}{c}1.923 * * * \\
(0.592)\end{array}$ & $\begin{array}{l}1.424 * * \\
(0.678)\end{array}$ \\
\hline Population's average age squared & & $\begin{array}{c}-0.032 * * * \\
(0.007)\end{array}$ & $\begin{array}{c}-0.027 * * * \\
(0.007)\end{array}$ & $\begin{array}{c}-0.023 * * * \\
(0.007)\end{array}$ & $\begin{array}{c}-0.022 * * * * \\
(0.007)\end{array}$ & $\begin{array}{l}-0.016^{*} \\
(0.008)\end{array}$ \\
\hline Coast dummy & & & $\begin{array}{c}-2.572 * * * \\
(0.258)\end{array}$ & $\begin{array}{c}-2.205^{* * *} \\
(0.335)\end{array}$ & $\begin{array}{c}-2.183 * * * \\
(0.347)\end{array}$ & $\begin{array}{c}-2.355 * * * \\
(0.379)\end{array}$ \\
\hline Distance to capital city & & & $\begin{array}{c}3.221^{* *} \\
(1.565)\end{array}$ & $\begin{array}{c}4.247 * * \\
(1.729)\end{array}$ & $\begin{array}{c}3.829 * * \\
(1.742)\end{array}$ & $\begin{array}{l}4.398 * * \\
(1.942)\end{array}$ \\
\hline Distance to capital city squared & & & $\begin{array}{l}-1.534 \\
(1.367)\end{array}$ & $\begin{array}{l}-2.626^{*} \\
(1.531)\end{array}$ & $\begin{array}{l}-2.352 \\
(1.535)\end{array}$ & $\begin{array}{l}-2.949^{*} \\
(1.686)\end{array}$ \\
\hline Capital city dummy & & & $\begin{array}{l}2.416^{*} \\
(1.272)\end{array}$ & $\begin{array}{c}2.635^{* *} \\
(1.29)\end{array}$ & $\begin{array}{l}2.534^{*} \\
(1.337)\end{array}$ & $\begin{array}{c}1.719 \\
(1.156)\end{array}$ \\
\hline Altitude & & & & $\begin{array}{c}0.001 \\
(0.001)\end{array}$ & $\begin{array}{c}0.001 \\
(0.001)\end{array}$ & $\begin{array}{c}0.001 \\
(0.001)\end{array}$ \\
\hline Ruggedness & & & & $\begin{array}{l}-0.003 * \\
(0.002)\end{array}$ & $\begin{array}{c}-0.002 \\
(0.002)\end{array}$ & $\begin{array}{l}-0.001 \\
(0.002)\end{array}$ \\
\hline Soil quality & & & & $\begin{array}{c}0.014 \\
(0.231)\end{array}$ & $\begin{array}{l}-0.092 \\
(0.246)\end{array}$ & $\begin{array}{c}0.02 \\
(0.262)\end{array}$ \\
\hline Rainfall & & & & $\begin{array}{c}0.106 \\
(0.066)\end{array}$ & $\begin{array}{c}0.091 \\
(0.065)\end{array}$ & $\begin{array}{c}0.025 \\
(0.087)\end{array}$ \\
\hline Average temperature & & & & $\begin{array}{l}-0.024 \\
(0.16)\end{array}$ & $\begin{array}{l}-0.034 \\
(0.162)\end{array}$ & $\begin{array}{c}0.012 \\
(0.182)\end{array}$ \\
\hline$R$-squared & 0.01 & 0.2 & 0.26 & 0.27 & 0.26 & 0.27 \\
\hline Obs. & 570 & 570 & 570 & 570 & 569 & 509 \\
\hline
\end{tabular}

Notes: Variables descriptions are provided in Table A1 (Supplementary Material). All regressions are estimated by OLS. The estimations include a constant term, which is omitted for space considerations. Robust standard errors are in parentheses. *,** and *** denote statistical significance at the 10,5 and $1 \%$ level, respectively. 
Table A5

Baseline model for different cutoffs of municipalities' population

\begin{tabular}{|c|c|c|c|c|c|c|c|}
\hline \multicolumn{8}{|c|}{ Dependent variable is Percentage of blood donors } \\
\hline & $\begin{array}{c}\text { All } \\
\text { municipalities } \\
(1) \\
\end{array}$ & $\begin{array}{c}>500 \\
\text { inhabitants } \\
\text { (2) }\end{array}$ & $\begin{array}{c}>1,000 \\
\text { inhabitants } \\
\text { (Baseline) } \\
(3)\end{array}$ & $\begin{array}{c}>2,000 \\
\text { inhabitants } \\
\text { (4) }\end{array}$ & $\begin{array}{c}>5,000 \\
\text { inhabitants } \\
\text { (5) }\end{array}$ & $\begin{array}{c}>10,000 \\
\text { inhabitants } \\
(6) \\
\end{array}$ & $\begin{array}{c}>20,000 \\
\text { inhabitants } \\
(7)\end{array}$ \\
\hline Land concentration in 1982 & $\begin{array}{c}-0.013^{*} * \\
(0.006)\end{array}$ & $\begin{array}{c}-0.015^{* *} * \\
(0.007)\end{array}$ & $\begin{array}{c}-0.022 * * * \\
(0.007)\end{array}$ & $\begin{array}{c}-0.024 * * * \\
(0.006)\end{array}$ & $\begin{array}{c}-0.028 * * * \\
(0.007)\end{array}$ & $\begin{array}{c}-0.03 * * * \\
(0.006)\end{array}$ & $\begin{array}{c}-0.029 * * * \\
(0.009)\end{array}$ \\
\hline Population & $\begin{array}{c}-0.025 * * * \\
(0.006)\end{array}$ & $\begin{array}{c}-0.025^{* * *} * \\
(0.006)\end{array}$ & $\begin{array}{c}-0.025 * * * \\
(0.006)\end{array}$ & $\begin{array}{c}-0.023 * * * \\
(0.006)\end{array}$ & $\begin{array}{c}-0.012 * * \\
(0.005)\end{array}$ & $\begin{array}{l}-0.007 * \\
(0.004)\end{array}$ & $\begin{array}{l}-0.005 \\
(0.005)\end{array}$ \\
\hline Population squared & $\begin{array}{c}30.669 * * * \\
(9.334)\end{array}$ & $\begin{array}{c}31.394 * * * \\
(9.457)\end{array}$ & $\begin{array}{c}31.325 * * * \\
(9.022)\end{array}$ & $\begin{array}{c}30.148 * * * \\
(8.875)\end{array}$ & $\begin{array}{c}17.426 * * \\
(7.162)\end{array}$ & $\begin{array}{l}10.693 * \\
(5.406)\end{array}$ & $\begin{array}{c}8.935 \\
(6.621)\end{array}$ \\
\hline Population's average age & $\begin{array}{c}2.493 * * * \\
(0.572)\end{array}$ & $\begin{array}{c}2.779 * * * \\
(0.614)\end{array}$ & $\begin{array}{c}2.112 * * * \\
(0.613)\end{array}$ & $\begin{array}{c}1.937 * * * \\
(0.666)\end{array}$ & $\begin{array}{c}4.118^{* * * *} \\
(1.113)\end{array}$ & $\begin{array}{c}4.412 * * * \\
(1.362)\end{array}$ & $\begin{array}{c}4.493 \\
(2.729)\end{array}$ \\
\hline Population's average age squared & $\begin{array}{c}-0.03 * * * \\
(0.007)\end{array}$ & $\begin{array}{c}-0.033^{* * *} * \\
(0.007)\end{array}$ & $\begin{array}{c}-0.024 * * * \\
(0.007)\end{array}$ & $\begin{array}{c}-0.022 * * * \\
(0.008)\end{array}$ & $\begin{array}{c}-0.052^{* * * *} \\
(0.014)\end{array}$ & $\begin{array}{c}-0.058 * * * \\
(0.018)\end{array}$ & $\begin{array}{l}-0.059 \\
(0.036)\end{array}$ \\
\hline Coast dummy & $\begin{array}{c}-2.159 * * * \\
(0.359)\end{array}$ & $\begin{array}{c}-2.121 * * * \\
(0.372)\end{array}$ & $\begin{array}{c}-2.27 * * * \\
(0.366)\end{array}$ & $\begin{array}{c}-2.214 * * * \\
(0.352)\end{array}$ & $\begin{array}{c}-2.214 * * * \\
(0.367)\end{array}$ & $\begin{array}{c}-2.738 * * * \\
(0.418)\end{array}$ & $\begin{array}{c}-2.587 * * * \\
(0.596)\end{array}$ \\
\hline Distance to capital city & $\begin{array}{c}7.701 * * * \\
(2.008)\end{array}$ & $\begin{array}{c}7.595 * * * \\
(2.061)\end{array}$ & $\begin{array}{c}5.487 * * * \\
(1.988)\end{array}$ & $\begin{array}{c}6.379 * * * \\
(2.026)\end{array}$ & $\begin{array}{c}4.754 * * \\
(2.359)\end{array}$ & $\begin{array}{c}5.863 * * \\
(2.54)\end{array}$ & $\begin{array}{c}2.648 \\
(3.056)\end{array}$ \\
\hline Distance to capital city squared & $\begin{array}{c}-5.232 * * * \\
(1.771)\end{array}$ & $\begin{array}{c}-5.489 * * * \\
(1.877)\end{array}$ & $\begin{array}{c}-3.554 * * \\
(1.773)\end{array}$ & $\begin{array}{c}-4.743^{* * * *} \\
(1.816)\end{array}$ & $\begin{array}{l}-2.267 \\
(2.225)\end{array}$ & $\begin{array}{l}-5.189 * \\
(2.764)\end{array}$ & $\begin{array}{l}-2.001 \\
(3.17)\end{array}$ \\
\hline Capital city dummy & $\begin{array}{l}3.396 * * \\
(1.354)\end{array}$ & $\begin{array}{c}3.322^{* * *} \\
(1.368)\end{array}$ & $\begin{array}{l}3.132 * * \\
(1.413)\end{array}$ & $\begin{array}{l}3.013^{* *} \\
(1.396)\end{array}$ & $\begin{array}{c}1.972 \\
(1.226)\end{array}$ & $\begin{array}{c}1.807 \\
(1.171)\end{array}$ & $\begin{array}{c}1.011 \\
(1.341)\end{array}$ \\
\hline Altitude & $\begin{array}{c}0.001 \\
(0.001)\end{array}$ & $\begin{array}{c}0.002 \\
(0.001)\end{array}$ & $\begin{array}{l}0.002 * \\
(0.001)\end{array}$ & $\begin{array}{l}0.002 * \\
(0.001)\end{array}$ & $\begin{array}{c}0.002 \\
(0.001)\end{array}$ & $\begin{array}{l}-0.001 \\
(0.001)\end{array}$ & $\begin{array}{l}-0.001 \\
(0.001)\end{array}$ \\
\hline Ruggedness & $\begin{array}{l}-0.001 \\
(0.002)\end{array}$ & $\begin{array}{l}-0.002 \\
(0.002)\end{array}$ & $\begin{array}{l}-0.003 * \\
(0.002)\end{array}$ & $\begin{array}{c}-0.005^{* *} \\
(0.002)\end{array}$ & $\begin{array}{c}-0.006^{* * * *} \\
(0.002)\end{array}$ & $\begin{array}{l}-0.002 \\
(0.002)\end{array}$ & $\begin{array}{c}0 \\
(0.003)\end{array}$ \\
\hline Soil quality & $\begin{array}{c}0.803 * * * \\
(0.254)\end{array}$ & $\begin{array}{c}0.588^{* *} * \\
(0.25)\end{array}$ & $\begin{array}{l}0.028 \\
(0.25)\end{array}$ & $\begin{array}{l}-0.089 \\
(0.239)\end{array}$ & $\begin{array}{l}-0.249 \\
(0.274)\end{array}$ & $\begin{array}{c}-0.727 * * \\
(0.332)\end{array}$ & $\begin{array}{l}-0.825 \\
(0.534)\end{array}$ \\
\hline Rainfall & $\begin{array}{l}-0.007 \\
(0.078)\end{array}$ & $\begin{array}{c}0.035 \\
(0.088)\end{array}$ & $\begin{array}{l}0.149 * \\
(0.085)\end{array}$ & $\begin{array}{c}0.08 \\
(0.096)\end{array}$ & $\begin{array}{c}-0.094 \\
(0.074)\end{array}$ & $\begin{array}{l}0.077 \\
(0.07)\end{array}$ & $\begin{array}{c}0.079 \\
(0.115)\end{array}$ \\
\hline Average temperature & $\begin{array}{c}-0.037 \\
(0.173)\end{array}$ & $\begin{array}{c}-0.021 \\
(0.179)\end{array}$ & $\begin{array}{c}0.09 \\
(0.187)\end{array}$ & $\begin{array}{c}-0.031 \\
(0.196)\end{array}$ & $\begin{array}{c}-0.132 \\
(0.205)\end{array}$ & $\begin{array}{c}-0.491 * * \\
(0.201)\end{array}$ & $\begin{array}{c}-0.291 \\
(0.302)\end{array}$ \\
\hline $\begin{array}{l}R \text {-squared } \\
\text { Obs. }\end{array}$ & $\begin{array}{r}0.17 \\
769\end{array}$ & $\begin{array}{c}0.18 \\
667\end{array}$ & $\begin{array}{c}0.24 \\
570\end{array}$ & $\begin{array}{c}0.31 \\
452\end{array}$ & $\begin{array}{l}0.39 \\
257\end{array}$ & $\begin{array}{c}0.49 \\
153\end{array}$ & $\begin{array}{c}0.49 \\
79\end{array}$ \\
\hline
\end{tabular}

Notes: Variables descriptions are provided in Table A1 (Supplementary Material). All regressions are estimated by OLS. The estimations include a constant term, which is omitted for space considerations. Robust standard errors are in parentheses. *, ** and $* * *$ denote statistical significance at the 10,5 and $1 \%$ level, respectively. 
Table A6

An alternative indicator of social capital: Turnout in general elections

Dependent variable is Turnout in general elections (average period 1989-2011)

\begin{tabular}{|c|c|c|c|c|c|c|}
\hline & (1) & (2) & (3) & (4) & (5) & (6) \\
\hline Land concentration in 1982 & $\begin{array}{c}-0.025 * * \\
(0.01)\end{array}$ & $\begin{array}{l}-0.02 * * \\
(0.009)\end{array}$ & $\begin{array}{c}-0.023^{* *} \\
(0.009)\end{array}$ & $\begin{array}{c}-0.023 * * \\
(0.01)\end{array}$ & & \\
\hline Land concentration in 1962 & & & & & $\begin{array}{c}-0.031 * * * \\
(0.008)\end{array}$ & \\
\hline Land concentration in 1930 & & & & & & $\begin{array}{c}-0.029 * * * \\
(0.008)\end{array}$ \\
\hline Population & & $\begin{array}{c}-0.107 * * * \\
(0.017)\end{array}$ & $\begin{array}{c}-0.093 * * * \\
(0.011)\end{array}$ & $\begin{array}{c}-0.097 * * * \\
(0.013)\end{array}$ & $\begin{array}{c}-0.096^{* * *} \\
(0.013)\end{array}$ & $\begin{array}{l}-0.1 * * * \\
(0.012)\end{array}$ \\
\hline Population squared & & $\begin{array}{c}151.446 * * * \\
(25.835)\end{array}$ & $\begin{array}{c}106.577 * * * \\
(15.815)\end{array}$ & $\begin{array}{c}109.532 * * * \\
(18.448)\end{array}$ & $\begin{array}{c}108.529 * * * \\
(18.014)\end{array}$ & $\begin{array}{c}147.307 * * * \\
(20.318)\end{array}$ \\
\hline Population's average age & & $\begin{array}{c}4.453 * * * \\
(1.002)\end{array}$ & $\begin{array}{c}3.774 * * * \\
(0.985)\end{array}$ & $\begin{array}{c}4.42 * * * \\
(1.004)\end{array}$ & $\begin{array}{c}4.334 * * * \\
(1.008)\end{array}$ & $\begin{array}{c}4.474 * * * \\
(1.291)\end{array}$ \\
\hline Population's average age squared & & $\begin{array}{c}-0.053^{* * *} * \\
(0.012)\end{array}$ & $\begin{array}{c}-0.046 * * * \\
(0.012)\end{array}$ & $\begin{array}{c}-0.052 * * * \\
(0.012)\end{array}$ & $\begin{array}{c}-0.052 * * * \\
(0.012)\end{array}$ & $\begin{array}{c}-0.053^{* * *} * \\
(0.015)\end{array}$ \\
\hline Coast dummy & & & $\begin{array}{c}-6.299 * * * \\
(0.738)\end{array}$ & $\begin{array}{c}-5.133 * * * \\
(0.891)\end{array}$ & $\begin{array}{c}-5.211 * * * \\
(0.894)\end{array}$ & $\begin{array}{c}-5.877 * * * \\
(0.948)\end{array}$ \\
\hline Distance to capital city & & & $\begin{array}{c}3.996 \\
(2.883)\end{array}$ & $\begin{array}{c}5.889 * * \\
(2.952)\end{array}$ & $\begin{array}{l}5.592 * \\
(2.985)\end{array}$ & $\begin{array}{l}5.654 * \\
(3.256)\end{array}$ \\
\hline Distance to capital city squared & & & $\begin{array}{l}-4.799 * \\
(2.482)\end{array}$ & $\begin{array}{c}-6.318 * * \\
(2.519)\end{array}$ & $\begin{array}{c}-6.027 * * \\
(2.506)\end{array}$ & $\begin{array}{c}-6.773 * * \\
(2.73)\end{array}$ \\
\hline Capital city dummy & & & $\begin{array}{c}10.109 * * * \\
(2.045)\end{array}$ & $\begin{array}{c}10.736 * * * \\
(2.182)\end{array}$ & $\begin{array}{c}10.644 * * * \\
(2.288)\end{array}$ & $\begin{array}{c}7.681 * * * \\
(1.74)\end{array}$ \\
\hline Altitude & & & & $\begin{array}{c}0.003 * * \\
(0.001)\end{array}$ & $\begin{array}{l}0.003 * \\
(0.001)\end{array}$ & $\begin{array}{l}0.003 * \\
(0.002)\end{array}$ \\
\hline Ruggedness & & & & $\begin{array}{l}-0.004 * \\
(0.002)\end{array}$ & $\begin{array}{l}-0.002 \\
(0.003)\end{array}$ & $\begin{array}{l}-0.003 \\
(0.003)\end{array}$ \\
\hline Soil quality & & & & $\begin{array}{c}1.332 * * * \\
(0.413)\end{array}$ & $\begin{array}{c}1.056 * * \\
(0.422)\end{array}$ & $\begin{array}{c}1.442 * * * \\
(0.445)\end{array}$ \\
\hline Rainfall & & & & $\begin{array}{l}-0.139 \\
(0.101)\end{array}$ & $\begin{array}{c}-0.144 \\
(0.099)\end{array}$ & $\begin{array}{c}-0.08 \\
(0.129)\end{array}$ \\
\hline Average temperature & & & & $\begin{array}{c}0.405 \\
(0.265)\end{array}$ & $\begin{array}{c}0.404 \\
(0.257)\end{array}$ & $\begin{array}{c}0.284 \\
(0.284)\end{array}$ \\
\hline$R$-squared & 0.01 & 0.19 & 0.32 & 0.35 & 0.36 & 0.37 \\
\hline Obs. & 568 & 568 & 568 & 568 & 567 & 507 \\
\hline
\end{tabular}

Notes: Variables descriptions are provided in Table A1 (Supplementary Material). All regressions are estimated by OLS. The estimations include a constant term, which is omitted for space considerations. Robust standard errors are in parentheses. *, ** and *** denote statistical significance at the 10, 5 and $1 \%$ level, respectively. 